\title{
Krigens folkeret
}

\section{Henrik Døcker}

\section{Klart og detaljerigt overblik over alle væsentlige begreber i krigens folkeret}

Ove Bring og Anna Körlof-Askholt: Folkrätt i krig, kris och fredsoperationer, Nordstedts Juridik $A B$, Stockholm 2011, 343 sider.

Det er måske ikke gået helt op for alle: Men en række vestlige lande er eller har nylig altså været i krig, ikke på den 'gammeldags' måde for at vinde territorium, eller fordi man er blevet angrebet, men som deltager i en intervention - som fx i Afghanistan, Irak eller Libyen. Det har i flere tilfælde vist sig vanskeligt at hitte rede $i$, hvad folkeretten havde at sige om denne og hin situation. Rigtig nyttigt er det derfor at stikke næsen ned i denne svenske bog om folkeretten i krig, kriser og fredsoperationer, hvis forfattere er hhv. pensioneret folkeretsprofessor og folkeretskyndig forsker ved SIPRI (Stockholm International Peace Research Institute).

Folkeretten kan, som forfatterne udtrykker det, kaldes en primitiv retsorden, som befinder sig i et tidligt udviklingsstadium, men med vis- se 'avancerede indslag'. Men virker de da, de folkeretlige normer, traktaterne, de internationale organisationers vedtagelser? Når man nu ikke har noget internationalt 'politi' og ofte ikke nogen international domstol til at sikre overholdelsen?

Forfatterne peger først (1) på staternes ønske om reciprok behandling. Man kunne som eksempel når dette nu her handler om krigens folkeret - tage behandling af krigsfanger, altså inden for et felt, hvor ingen domstol umiddelbart vil dømme for brud på Geneve-konventionerne, lad os sige i forbindelse med en afhøring. Man behandler ikke fjendens soldater meget brutalt af frygt for en gengældelse fra fjendens side over for ens egne soldater.

Dernæst (2) har staterne en vis respekt/frygt for den internationale opinion eller FN, og endelig frygter de (3): Risikoen for repressalier eller sanktioner.

Krigens folkeret er blevet genstand for adskillige bøger i de senere år, herunder også fra danske juri- 


\section{LITTERATUR}

ster som Peter Vedel Kessing og Anders Henriksen, og alle sagkyndige på området vil ikke være enige i alt, hvad nu Bring og Körlof-Askholt fremfører. Som de ser det kan 'krigens love' siges at omfatte tre adskilte regelkomplekser: 1) humanitær ret, 2) neutralitetsret og 3) okkupationsret. Det første kompleks omfatter, hvad der måske oftest er fokus på i verdensoffentligheden: Regler for krigsførelse som sådan og regler om beskyttelse af krigens ofre.

Det er værd at bemærke, at ordet krig reelt er forladt af folkeretsjuristerne, det findes end ikke som opslagsord i adskillige folkeretsbøger. Det hele begyndte med, at begrebet krigserklæring så at sige gik af mode. I virkeligheden skete det kort efter Første Verdenskrig, at stater gik til angreb på andre stater uden en sådan erklæring, og de fire Røde KorsGeneve-konventioner af 1949 kom da også til at afspejle dette.

Det almindeligvis benyttede udtryk er blevet væbnet konflikt, som så yderligere har den 'fordel', at det lader det stå åbent, om der er tale om en international konflikt eller en borgerkrig. Da nutidens borgerkrige i flere tilfælde er blevet 'forsynet' med en intervention udefra fra et eller flere lande, som er kommet en part i borgerkrigen til undsætning (som til eksempel Libyen), er overgangen mellem de to typer krige blevet udflydende. Man kan også sige, at forskellen mellem dem er blevet mindre.

\section{Det begyndte i Haag}

Den moderne krigsfolkeret kan siges at være undfanget af den første Haag-konference i 1899, indkaldt på russisk initiativ med nedrustning på dagsordenen: Rusland var opskræmt af en betydelig oprustning i Prøjsen. Konferencen indskrev sig i historien, fordi de 26 deltagende stater (og deriblandt Danmark) bl. a. enedes om at forbyde de såkaldte dumdum-kugler, opkaldt efter Dam Dama, den by nær Calcutta i Britisk Indien, hvor disse kugler, som deformeredes i menneskekroppen, blev fremstillet. Læger, der havde forsøgt at operere soldater, som var såret af kuglerne, havde protesteret voldsomt mod dem. Det kan tilføjes, at forbuddet internationalt kun gælder for militære styrker og altså formelt ikke politiet.

Siden hen kom forbud mod gift og forgiftede våben eller våben, som forårsagede unødig stor lidelse. Tysklands brug af forskellige gasarter i Første Verdenskrig kom imidlertid til at kræve 100.000 dødsofre, men i alt 1,3 mio. blev angrebet af gasserne, og mange pådrog sig livsvarige lidelser. Trods senere tiders forbud mod brug af gas eller bakteriologiske våben skulle vi i nutiden opleve et eksempel på benyttelse af sarin og klorgas, nemlig da Iraks diktator Saddam Hussein i 1998 gik til angreb på den kurdiske befolkning i den irakiske by Halabja, hvorved 5000 mennesker omkom. Det 
skyldtes USA's daværende frygt for Iran som et væsentligt større onde end Irak, at denne forbrydelse ikke blev mødt med voldsomme sanktioner fra USA's side - noget bogen ikke kommer ind på. Læs: Sammantha Power: A problem from Hell - America and the Age of Genocide, (New York 2003).

Bogen redegør i mange detaljer for alle nutidens konventioner til fremme af nedrustningen og for at humanisere krigsførelsen ved forbud mod kemiske våben, fragmentationsbomber, anti-personelminer, klyngevåben mv. Bogen medtager fortjenstfuldt oplysning om, at der i dag skønnes at være spredt omkring 100 mio. landminer over i alt 70 stater. De i så henseende hårdest ramte lande er Afghanistan, Angola, Bosnien-Hercegovina, Cambodja, Irak, Kuwait, Mocambique, Somalia og Vestsahara. Det kan tilføjes, at FN og en række vestlige stater er engageret i minerydning af betydeligt omfang.

\section{Fredsbevarende - og fredsskabende}

Det interessante ved FN's fredsbevarende operationer - lige fra udsendelse af ubevæbnede observatører til egentlige fredsstyrker, der kun må bruge deres våben i selvforsvar er, at de ikke er nævnt i FN-pagten. Enhver vidste i 1945, at afslutningen på Anden Verdenskrig og FN's oprettelse på ingen måde sikrede freden. Alene den forestående afvikling af en række historie-tunge euro- pæiske magters kolonier frembød faresignaler. Denne bog kommer ikke ind på det, men det fremgår af tilkendegivelser fra officiel amerikansk side allerede under krigen, at USA imødeså en sådan udvikling. FN's første medvirken til at forebygge eller mindske væbnet konflikt var, da en undersøgelseskommission i 1947 blev udsendt til Indonesien, hvis befolkning havde iværksat en guerilla-krig for at slippe fri af Holland.

Så fulgte Mellemøsten (Israels fødsel) og Indien (Kashmir) - og ingen af disse to områder kan siges at være faldet til ro. Bogen sætter ikke tal på det hidtidige antal FNoperationer, men det kan tilføjes, at de andrager 64 alt iberegnet. Disse missioner er tænkt som midlertidige, og mandaterne fornys ofte kun med et halvt år ad gangen. En del har været svært sejlivede - den på Cypern (for at hindre græesk- og tyrk-cyprioterne $\mathrm{i}$ atter at gribe til fjendtligheder) har således været der siden 1964.

Interessant er, at de traditionelt fredsbevarende styrker i BosnienHercegovina også blev fredsskabende i og med konfliktens eskalering. FN-styrken UNPROFOR kunne dermed ikke undgå at blive part i konflikten mellem serbiske styrker og den bosniakiske befolkning, noget FN ellers havde forsøgt at undgå, siden det i 1960 blev involveret i den daværende borgerkrig i det netop uafhængige Congo. Bring har i en 


\section{LITTERATUR}

tidligere bog Internationell våldsanvänding ock folkrätt (Stockholm 2006) redegjort nærmere for FNfredsstyrkers almindelige opgaver og for FN-Sikkerhedsrådets rolle i forbindelse med en del internationale interventioner samt nyeste tids terrorbekæmpelse.

De udsendte styrker skal overholde menneskerettighederne. Det fremgår af et par domme fra Den Europæiske Menneskerettighedsdomstol, som er faldet efter bogens udgivelse, at Storbritannien kunne holdes ansvarlig (og dermed erstatningspligtig over for de efterladte) for, at britiske styrker i Irak under et natligt raid affyrede dødelige skud mod nogle iraker. Det samme var tilfældet for Frankrig i Kosovo, hvor nogle dertil udsendte soldater holdtes ansvarlige for en sprængning af en forsager, som forvoldte en drengs $\mathrm{d} ø \mathrm{~d}$. Internationale organisationer så som FN eller NATO nyder immunitet og kan ikke holdes ansvarlige, eftersom de ikke er 'part' eller 'signatarmagt' til internationale ansvarspålæggende traktater.

\section{Okkupation i forskellige former}

Begrebet besættelse eller okkupation har ikke været indgående behandlet i alle folkeretslærebøger. Faktisk kan man lede forgæves efter det i diverse indeks. Her fastslås det indledningsvis, at en okkupation så at sige pr. definition - er en midlertidig militær magtovertagelse. Det kan måske synes selvfølgeligt, men godt at få fastslået, så at sige med ‘juridiske syvtommersøm’: Okkupationsmagten har ansvaret for civilbefolkningen i det besatte område. Såvel Tyskland som Sovjetunionen overflyttede under Anden Verdenskrig mange mennesker fra besatte fremmede områder til sig selv. Okkupationsmagter skal også sørge for forsørgelse af befolkningerne i de besatte områder - det kom USA og Storbritannien således til at føle i Irak.

Emnet forekommer mig at være en kende mere indviklet, end de to svenske forfattere fremstiller det under deres opregning af diverse eksisterende konventioner, herunder Geneve-konventionerne. Vigtigt er det at forstå, at en okkupation er ensbetydende med en fortsat krigstilstand - eller, om man vil, en tilstand af væbnet konflikt, som altså kan give okkupanten ret til internering af civile uden striks iagttagelse af, hvad der i engelsk ret kaldes $h a-$ beas corpus, i dansk terminologi 'grundlovsforhør', altså ved tilbageholdelse af folk et krav om, at de fremstilles for en dommer inden udløbet af 24 timer. Dernæst er der jo tilfælde af, hvad man kunne kalde 'fredelig besættelse', så som udsendelsen af ca. 30.000 tyrkiske soldater til Nordcypern - de kom oprindelig efter anmodning fra nordcyprioterne, og siden er deres tilstedeværelse blevet sanktioneret af den regering, der blev dannet efter en løsrivelse 
fra republikken Cypern. Her er den tyrk-cypriotiske befolkning på Nordcypern så kommet i karambolage med den øvrige verden (undtagen Tyrkiet), eftersom både FN og Europarådet har erklæret denne løsrivelse for folkeretsstridig.

Med sin tilstedeværelse (som godt nok har antaget karakter af at være permanent) har Tyrkiet imidlertid aldrig været på Cypern i erobringsøjemed. Spørgsmålet er så ladet med politik, at de folkeretskyndige ikke vil røre det med en ildtang, så man må tilgive de to svenske forfattere, at de heller ikke tager det op. Taiwans dannelse som stat - efter Chiang Kai-sheks prætention om at repræsentere hele Kina i 1978 blev brudt - kan vel også kaldes mere end ekstraordinær, men denne stat (så lidt som Nordcypern medlem af FN) sættes der mærkværdigvis aldrig spørgsmålstegn ved.

Bring og Körlof-Askholt bringer ikke her Israels okkupation af Vestbredden (Vestjordanlandet) ind $\mathrm{i}$ billedet, men Bring har i et andet betydeligt værk De mänskliga rättigheternas väg - genom historien og litteraturen, (Stockholm, 2011), fastslået, at Israel, uanset om det nu handlede i selvforsvar eller gik til angreb, da Seksdageskrigen brød ud i 1967, for længst skulle have have afsluttet denne besættelse. Alene fordi den er blevet permanent, er den ulovlig. Og for nu at gå i nogle folkeretlige detaljer, så må en okkupationsmagt efter den 4. Geneve (Røde Kors)konventions art. 49 ikke overflytte sin egen befolkning (her: de israelske bosættere) til et okkuperet område. Fremdeles bør en besættelsesmagt - efter art. 55 i det såkaldte Landkrigsreglement (til 4. Haagkonvention af 1907) - beskytte værdien af sådan noget som landbrug og alene betragte sig som en administrator af den fremmede ejendom.

Dette strejftog gennem en meget betydelig materie, mange regler og udlægninger af disse - og også en del gode eksempler på eklatant overtrædelse af dem - giver stof til megen eftertanke. De sætter den krigeriske nutidshistorie i et mangeartet perspektiv og giver noget af forklaringen på, hvorfor fx dansk militær har haft det rigtig svært i mange situationer i Irak, når indsatsreglerne (rules of engagement) ikke har været klare nok, eller de udsendte ikke var fortrolige nok med dem.

Alt sammen svært beklageligt i disse unaturlige situationer, hvor mennesker fra vor verdensdel skal udkæmpe andres krige i fjerne lande.

Henrik Døcker er journalist og forfatter med speciale i menneskerettigheder. 